\title{
Clinicopathological, histochemical and immunohistochemical aspects of angioleiomyoma of the cheek: a case report
}

\author{
Paula Daniele Matheus ${ }^{a}$, Manoela Domingues Martins ${ }^{a}$, Luise Meurer ${ }^{b}$, Lucas N. Sant'Ana ${ }^{a}$, Manoel Santa'Ana Filho ${ }^{a}$
}

\begin{abstract}
Introduction: Leiomyomas are benign smooth muscle neoplasms that preferably affect the genitals, skin, and gastrointestinal tract, being rarely seen in the oral cavity. They are commonly classified into three microscopic patterns: solid leiomyoma, angioleiomyoma (ALM), and epithelioid leiomyoma. The most frequently reported sites of occurrence of oral ALM are the lip (48.6\%), palate (21.1\%), buccal mucosa and tongue (9.2\%), and intraosseous lesions (8.3\%).

Case report: A 62 years old male presented a painless swelling in the left cheek. In this report histopathological and immunohistochemical analysis were made to confirm the diagnosis, since several lesions were possible. The treatment was local surgical excision of the tumor.
\end{abstract}

Key words: Angioleiomyoma; Smooth muscle neoplasms; Benign neoplasm; Oral lesions

\section{Aspectos clinicopatológicos, histoquímicos e imunoistoquímicos de angioleiomioma de mucosa jugal: relato de caso}

\section{RESUMO}

Introdução: Leiomiomas são tumores benignos de músculo liso que afetam preferencialmente os genitais, pele e do trato gastrointestinal, sendo raramente visto na cavidade bucal. Esses tumores são comumente classificados em três padrões microscópicos: leiomioma sólido, angioleiomioma (ALM), e leiomioma epitelióide. Os locais mais freqüentemente afetados por ALM na boca são: lábio (48,6\%), palato (21,1\%), mucosa jugal e língua $(9,2 \%)$ e intra-óssea $(8,3 \%)$.

Relato de caso: Paciente de 62 anos, masculino apresentou um inchaço indolor na bochecha esquerda. Neste relato de caso foram realizadas análises histopatológicas e imuno-histoquímico para confirmar o diagnóstico, uma vez que várias lesões podem fazer diagnóstico diferencial. O tratamento foi excisão cirúrgica local do tumor.

Palavras-chave: Angioleiomioma; Neoplasias de musculatura lisa; Neoplasia benigna; Lesões bucais a Oral Pathology,School of Dentistry, Universidade Federal do Rio Grande do Sul (UFRGS), Porto Alegre, Brazil

${ }^{b}$ Pathology Department, School of Medicine, Universidade Federal do Rio Grande do Sul, Porto Alegre, Brazil 


\section{INTRODUCTION}

Leiomyomas are benign smooth muscle neoplasms that preferably affect the genitals, skin, and gastrointestinal tract, being rarely seen in the oral cavity. They are commonly classified into three microscopic patterns: solid leiomyoma, angioleiomyoma (ALM), and epithelioid leiomyoma [1]. ALM accounts for about two thirds of all benign smooth muscle tumors of the oral cavity and exhibits prominent vascular channels. Regarding the origin of oral cavity leiomyomas, it has been proposed that these tumors arise from vascular smooth muscle [2]. Clinically, ALM most often appears as painless, slow-growing, nodular lesions that may vary in size from a few millimeters to $2 \mathrm{~cm}$. larger lesions are seldom seen. The most frequently reported sites of occurrence of oral ALM are the lip (48.6\%), palate $(21.1 \%)$, buccal mucosa and tongue $(9.2 \%)$, and intraosseous lesions (8.3\%) [3]. Histologically, the lesion is well circumscribed, with a partial to full-thickness capsule that contains numerous vascular spaces surrounded by thickened muscular walls of varying sizes. A varied mix of collagen fibers and smooth muscle fibers can be observed within these vascular spaces, with smooth muscle fibers exhibiting characteristic eosinophilic cytoplasm and cigar-shaped nuclei. The smooth muscle origin of the tumor is confirmed immunohistochemically with antibodies to smooth muscle actin $[4,5]$. In this study we will present a case of angioleiomyoma of the cheek with histopathological and immunohistochemical analysis.

\section{CASE REPORT}

A 62 years-old, man, Caucasian, presented an asymptomatic growing mass involving the left cheek with signs of progression for several years (Fig. 1). Physical examination revealed an increased volume in the left cheek, without signs of inflammation. A well-defined, mobile, non-tender mass measuring approximately $2 \times 2 \mathrm{~cm}$ was palpated. Intraoral examination showed the buccal mucosa with normal color and intact overlying tissue. External digital pressure moved the lesion toward the oral cavity. The lesion was surgically excised and removed completely
(Fig. 2a and 2b), than submitted for macroscopic (Fig. 2b) and microscopic evaluation. The specimen was processed and histopathological examination revealed a neoplasm lesion well circumscribed characterized by an abnormal proliferation of mesenchymal spindle-shaped cells with eosinophilic cytoplasm and tapered nuclei. Several vascular formations, with thick- and thin-walled vessels, were observed (Fig. 3a and 3b). The stroma showed a fibrous connective tissue with inflammatory cells and focal hemorrhagic areas. The diagnosis based on haematoxylin and eosin staining was angioleiomyoma. To distinguish the muscle and fibrous component a Masson trichrome staining was performed. It revealed smooth muscle tumor cells stained by red surrounded by blue labeling of fibrous tissue (Fig. 3c and 3d). A panel including the following immunohistochemical markers was done with the aim to illustrate the case and HHF35 (also is known as muscle specific actin), S-100 protein, AE1-AE3, desmin, CD31, and Ki-67 were investigated. Tumor cells were strongly immunopositive for HHF35 (Figures 3e and 3f) and CD31, just the endothelial lining cells. Low score of Ki-75 was observed. On the other hand, these cells were negative to S-100 protein, AE1-AE3, desmin.

No recurrence was observed after 3-year follow-up (Fig. 4).

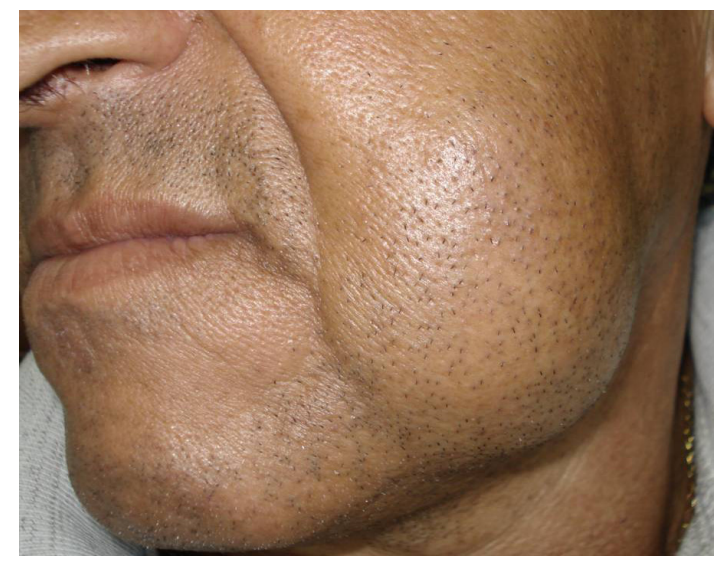

Figure 1. Patient with a growing mass involving the left cheek.
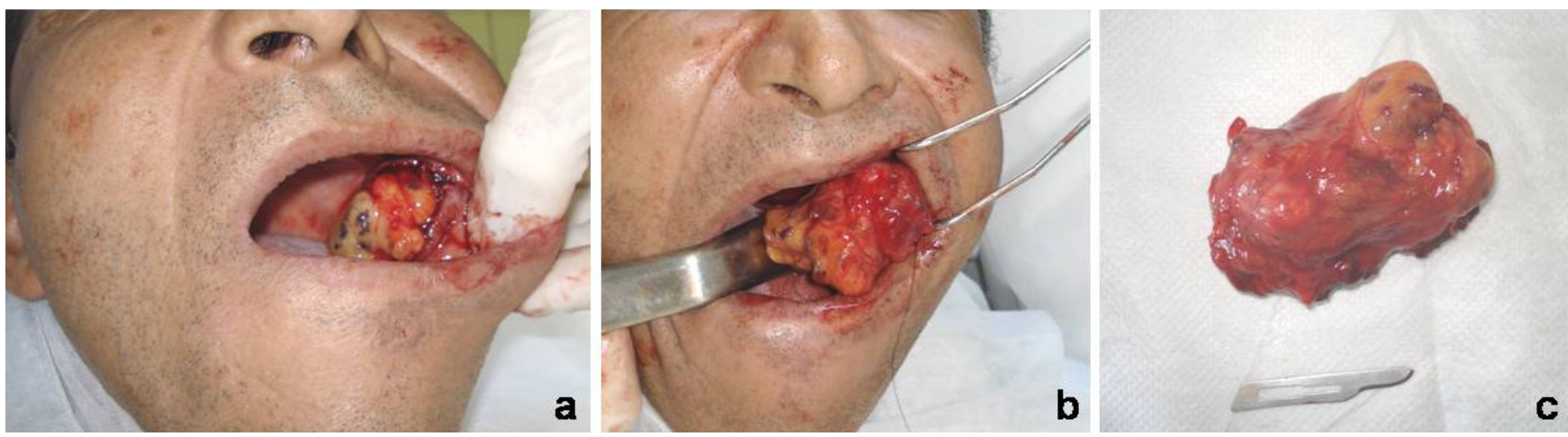

Figure 2. Angioleiomyoma. (a) and (b) The clinical aspect of surgical procedure. (c) Macroscopic view of surgical specimen. 

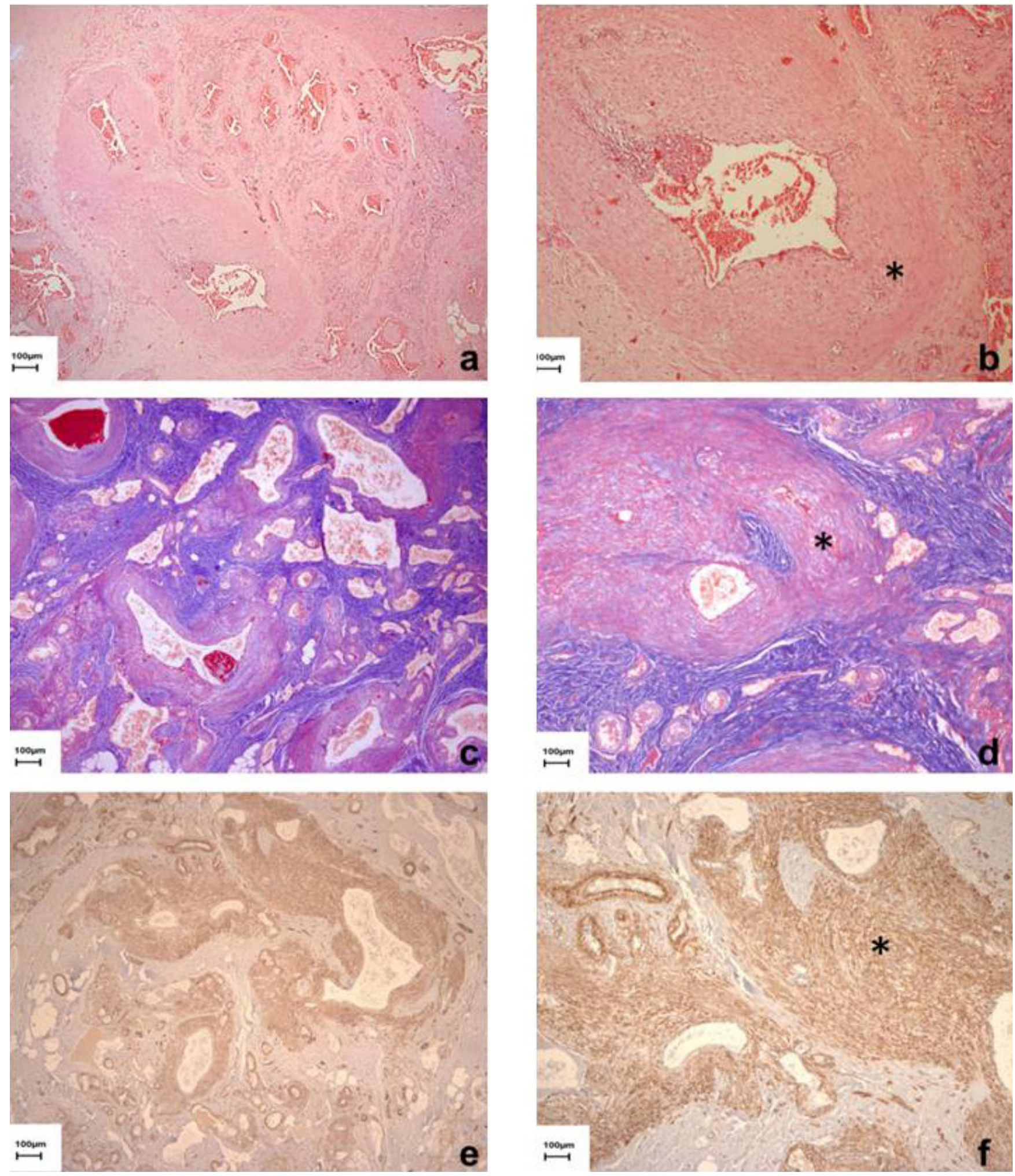

Figure 3. Angioleiomyoma. (a) Histopathological examination reveals a numerous vessels interlacing smooth muscle and collagen fibers (haematoxylin \& eosin, original magnification, x40). (b) Higher power histopathological examination shows a vascular space surrounded by a thick muscular wall (asterisk) (haematoxylin \& eosin, original magnification, x100). (c, d) The angioleiomyoma demonstrates a spindle-shaped cells (red stain, asterisk) proliferation around the blood vessels and a collagen stroma (blue stain). (Masson trichrome, original magnification, c x40 and d x100). (e, f) The muscle cells (asterisk) exhibit a strongly immunopositivity for HHF35. (Streptavidin-biotin immunoperoxidase stain, original magnification $\times 40$ and $\mathrm{f} \times 100)$. 

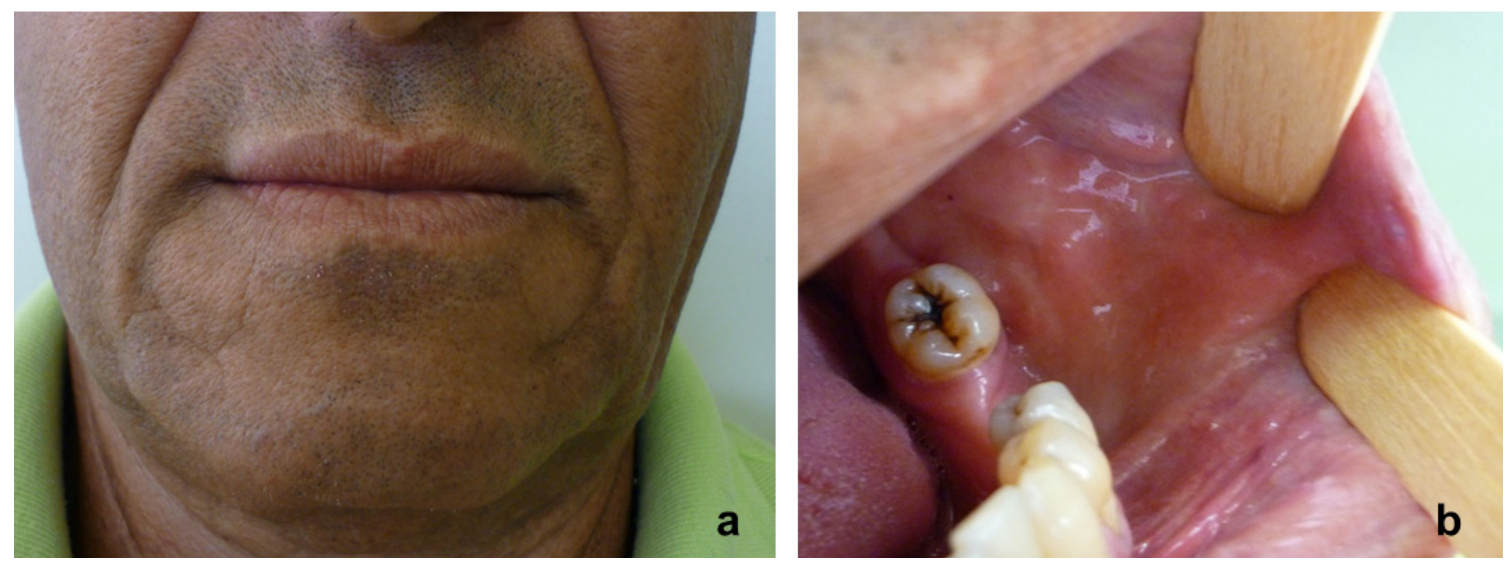

Figure 4. Extra oral (a) and intra oral (b) view showing no recurrence after 3-year follow-up period.

\section{DISCUSSION}

Upon oral examination and review of the pertinent medical and social history, a number of pathological processes should be considered. Taking into account the length of time the lesion remained unchanged and the nonulcerated nature of the lesion - a slow-growing, solitary, deep-seated, encapsulated nodule - a benign process was considered most likely. The differential diagnosis should include salivary gland neoplasms (e.g., pleomorphic adenoma), mesenchymal neoplasms (e.g., lipoma, schwannoma or neurofibroma) [6].

Salivary gland neoplasms were our main differential diagnosis. Pleomorphic adenoma was considered the most likely possibility, although malignant salivary tumors such as the Mucoepidermoid carcinoma can also be considered, but most unlikely since the bounds of the lesion were surgically visible. Pleomorphic adenoma is the most common minor salivary gland tumor, occurring most often in women in their third to fourth decade. Pleomorphic adenomas typically appear as symptom-free, smooth-surfaced, compressible soft tissue nodular lesions that rarely show a bluish ulceration resulting from trauma [7].

Mesenchymal neoplasms should also be considered, including lipoma, schwannoma and neurofibroma [8]. These lesions would appear as asymptomatic nodular lesions, often with normal tissue coloration. Malignant mesenchymal neoplasms can be reasonably excluded due to the longstanding stable nature of the lesion. In superficial lipomas a yellow color at the surface can be seen, however in profound lesions it is impossible to clinically distinguish from other lesions, and the buccal mucosa is one of the most common sites of lipoma. Schwannomas occur predominantly in children and young adults and tend to present as slowly enlarging nodules that may be associated with pain. Similar to the lesions previously reported here, schwannomas are typically nonulcerated unless secondarily traumatized. Neurofibroma is the most common peripheral nerve sheath neoplasm.

Local surgical excision of the tumor with an adequate margin of normal tissue is the treatment of choice. Although angioleiomyomas derive from vascular smooth muscle cells, excessive bleeding is rarely seen. Moreover, recurrences of oral lesions are notably rare [9].

\section{CONCLUSION}

This case demonstrates to the clinician that lesions located in the buccal mucosa may translate into unexpected outcomes in the final diagnosis, but a correct clinical management can lead to successful treatment.

\section{REFERENCES}

1. Grossmann SMC, Johann ACR, Castro WH, et al.: Anterior midline nodule of the hard palate. Oral Surg, Oral Med, Oral Pathol, Oral Radiol Endod 2009;108:808-11. https://doi.org/10.1016/j.tripleo.2009.06.025

2. Scheper MA, Nikitakis NG, Meiller TF: A stable swelling of the hard palate. Oral Surg, Oral Med, Oral Pathol, Oral Radiol Endod 2007;104:461-4 https://doi.org/10.1016/j.tripleo.2007.03.018

3. Gueiros LA, Romanach MJ, Pires-Soubhia AM, Pires FR, Paes-de-Almeida O, Vargas PA: Angioleiomyoma affecting the lips: report of 3 cases and review of literature. Med Oral Patol Oral Cir Bucal 2011;16:e482-7. https:// doi.org/10.4317/medoral.16.e482

4. Baden E, Doyle JL, Lederman DA: Leiomyoma of the oral cavity: a light microscopic and immunohistochemical study with review of the literature from 1884-1992. Oral Oncol Eur J Cancer 1994:30B:1-7. https://doi. org/10.1016/0964-1955(94)90043-4

5. Brooks JK, Nikitakis NG, Goodman NJ, et al. Clinicopathologic characterization of oral angioleiomyomas: Oral Surg, Oral Med, Oral Pathol, Oral Radiol Endod 2002;94:221-7. https://doi.org/10.1067/ moe.2002.125276

6. Wertheimer-Hatch L, Hatch GF III, Hatch KF, Davis GB, Blanchard DK, Foster RS Jr, et al.: Tumors of the oral cavity and pharynx. World J Surg 2000;24:395-400. https://doi.org/10.1007/s002689910064

7. Toida M, Shimokawa K, Makita H, Kato K, Kobayashi A, Kusunoki Y, Hatakeyama D, Fujitsuka H, Yamashita T, Shibata T. Intraoral minor salivary gland tumors: a clinicopathological study of 82 cases. Int J Oral Maxillofac Surg. 2005;34:528-32. https://doi.org/10.1016/j.ijom.2004.10.010

8. Kim HY, Jung SN, Kwon H, Sohn WI, Moon SH. Angiomyoma in the buccal space. J Craniofac Surg. 2010;21:1634-5. https://doi.org/10.1097/ SCS.0b013e3181ef67f1

9. McParland H, Warnakulasuriya S, Cook RJ. Angioleiomyoma: an unusual diagnosis for a lump in the cheek. Br J Oral Maxillofac Surg. 2009;47: 641-2. https://doi.org/10.1016/j.bjoms.2008.12.008 